Human Rights and

Disability Advocacy 
PENNSYLVANIA STUDIES IN HUMAN RIGHTS

Bert B. Lockwood, Jr., Series Editor

A complete list of books in the series

is available from the publisher. 


\section{Human Rights and Disability Advocacy}

Edited by

Maya Sabatello

and

Marianne Schulze

\section{PENN}

UNIVERSITY OF PENNSYLVANIA PRESS

PHILADELPHIA 
Copyright @ 2014 University of Pennsylvania Press

All rights reserved. Except for brief quotations used for purposes of review or scholarly citation, none of this book may be reproduced in any form by any means without written permission from the publisher.

\author{
Published by \\ University of Pennsylvania Press \\ Philadelphia, Pennsylvania 19104-4112 \\ www.upenn.edu/pennpress \\ Printed in the United States of America \\ on acid-free paper \\ $\begin{array}{llllllllll}10 & 9 & 8 & 7 & 6 & 5 & 4 & 3 & 2 & 1\end{array}$

\section{Library of Congress Cataloging-in-Publication Data}

Human rights and disability advocacy / edited by Maya Sabatello and Marianne Schulze - 1st ed.

p. cm. - (Pennsylvania studies in human rights)

Includes bibliographical references and index.

ISBN 978-0-8122-4547-9 (hardcover : alk. paper)

1. People with disabilities—Civil rights-History. 2. People with disabilities—Legal status, laws, etc.-History. 3. Human rights advocacy-History. 4. Convention on the Rights of Persons with Disabilities and Optional Protocol (2007 March 30) 5. Nongovernmental organizations-Political activity. 6. Civil society. I. Sabatello, Maya. II. Schulze, Marianne, 1975-. III. Series: Pennsylvania studies in human rights. HV1568.H855 2013

$323.3-\mathrm{dc} 23$ 
Worse than not seeing and not hearing is not to be seen and not to be heard.

-Helen Keller 
This page intentionally left blank 